\title{
SWOT Analysis of TEFA Breeding and Hatchery Business Development at Jember State Polytechnic
}

\author{
Budi Prasetyo ${ }^{1}$, Gayuh Syaikhullah ${ }^{2 *}$ and Reikha Rahmasari ${ }^{3}$ \\ ${ }^{I}$ Animal Science Department, Politeknik Negeri Jember, Indonesia \\ ${ }^{2}$ Animal Science Department, Politeknik Negeri Jember, Indonesia \\ ${ }^{3}$ Animal Science Department, Politeknik Negeri Jember, Indonesia \\ *Corresponding author.Email: gayuh_syaikhullah@polije.ac.id
}

\begin{abstract}
This study aims to analyze the strengths, weaknesses, opportunities, and threats of the breeding business developed by TEFA Breeding and Hatchery at the Jember State Polytechnic and determine the most appropriate strategy to implement. Strengths and weaknesses are evaluated from internal teaching factory factors, while opportunities and threats are evaluated from external factors that affect the livestock. These factors were then analyzed using the Strength, Weakness, Opportunity, and Threat (SWOT) matrix. The results showed that there was a constant increase in the demand for DOC and no other substitutes had a significant effect. So this condition was identified as an opportunity in the livestock business. Meanwhile, the varying DOC prices are a threat. Meanwhile, the internal factor that most influences strategic planning is the imperfect production flow for larger production capacity. As a result of the SWOT analysis, several strategies can be implemented in a future implementation, namely increasing genetic quality and product quantity. It was hoped that DOC sales would continue to increase. In addition to improving product quality and quantity, another strategy that was expected to be implemented was to establish Standard Operating Procedures (SOPs) as effectively and efficiently as possible.
\end{abstract}

Keywords: breeding and hatchery, day-old chick, kampung chicken, SWOT analysis

\section{INTRODUCTION}

Local chickens are a key resource in the development of superior chicken breeds that have been shown to adapt to the local environment [1]. Local chicken is one of the factors that contribute to Indonesia's demand for animal protein. As the public becomes more aware of the importance of eating nutritious meat, local chicken meat has become fairly popular. Broiler chicken provides some advantages over local chicken flesh. The mineral content of local chicken flesh is higher, and the cholesterol level is lower. Local chicken is significantly more expensive than broilers from an economic standpoint. Local chickens, on the other hand, have a slower production ratio than broilers [2]. As a result, academics must make efforts to identify a medium ground to solve this dilemma.

analysis, the identification of internal factors and external factors that can be used as the basis for
Selection and genetic improvement are one way to develop the potential of local chickens as a stimulus for a more optimal farming business in the future. From the research results, TEFA Breeding and Hatchery of Jember State Polytechnic are currently producing DOC (Day Old Chicken) Kampung Super which is the result of genetic improvement from local chickens. The results of this research are expected to be able to stimulate local breeders to cultivate local chickens.

To follow up on the activities that have been carried out by TEFA Breeding and Hatchery, it is necessary to have a business feasibility test in the cultivation of these Kampung Super chickens. This is to see the potential for the cultivation of this new local chicken variety among the community. In this testing process, a SWOT analysis and maintenance trials will be carried out directly by local farmers. In the SWOT making a business development strategy will be carried out [3]. It is hoped that the results of this 
activity will receive an evaluation from the farmers directly regarding the improvements that need to be made in the future so that the cultivation of super native chickens resulting from the TEFA Breeding \& Hatchery Breeding Jember State Polytechnic can become a profitable and sustainable livestock business.

\section{METHOD}

Internal (strengths, weaknesses) and external (opportunities, threats) factors that existed in TEFA Breeding \& Hatchery Jember State Polytechnic, as well as formulating the right strategy to be applied to local broiler farming businesses in local livestock groups, particularly in Kabupaten Jember, were the focus of the research.

From Figure 1, it can be seen that the SWOT analysis begins by analyzing the internal environment, namely: Product, price, distribution, facilities, and human resources factors, as well as analyzing external factors, namely economic, competitor, socio-cultural, and technological factors. By comparing the external factors of opportunities and threats with the internal factors of business strengths and weaknesses. The results of the analysis carried out then interpreted and developed into a decision on the selection of a development strategy that allows it to be implemented. The strategy is chosen usually produces the most probable results with the least risks and threats.
This research was conducted on a group of chickens in Jember regency which is the subject of this study. Meanwhile, the object of this research is the strategy for developing DOC (day old chicken) livestock cultivation of super native chickens as a result of genetic improvement that has been carried out by TEFA Breeding and Hatchery at the Jember State Polytechnic.

There were three ways of collecting data, namely (1) Observation or field survey, namely direct research on the environment conditions of TEFA Breeding \& Hatchery to determine real conditions around the research object. (2) Interview, the activities to collect information for research purposes by asking some questions to TEFA management, staff, and stakeholder (farmer). (3) Documentation and literature study, this method is used to collect related data and literature relevant to this research.

\section{RESULTS}

SWOT analysis is one tool used to analyse the managerial process and to compile corporate strategic factors on business development [4] [5]. In this study, researchers divided two factors that influence the development of TEFA breeding and hatchery, namely internal factors: product, price, promotion, distribution, facilities and human resource, and the external factors: economic, competitor, socio-cultural and technology.
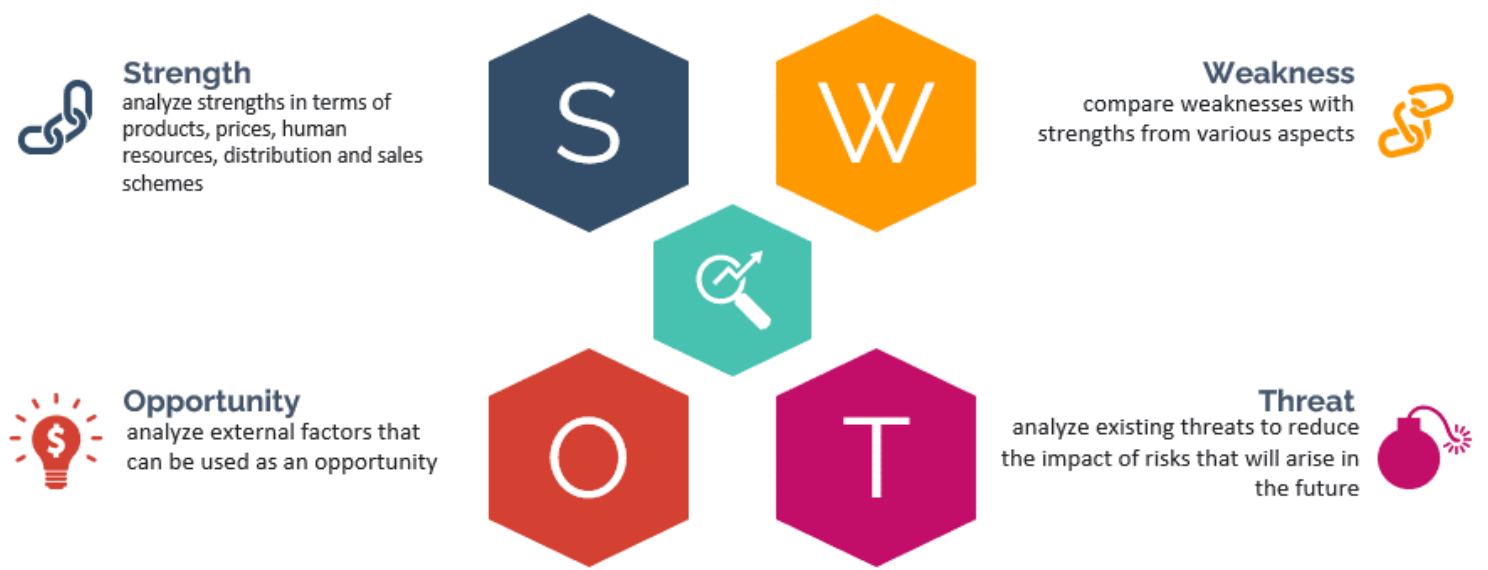

Figure 1 SWOT analysis elements

Table 1. Internal factors analysis

\begin{tabular}{|l|l|l|}
\hline $\begin{array}{l}\text { Internal factor } \\
\text { strategies }\end{array}$ & Strengths & Weaknesses \\
\hline Product & $\bullet \begin{array}{l}\text { Product quality (local chicken } \\
\text { DOC) }\end{array}$ & $\bullet$ Production capacity \\
\hline Price & $\bullet$ Price can compete & $\begin{array}{l}\text { Underestimated quality by lower } \\
\text { price }\end{array}$ \\
\hline Promotion & $\bullet \begin{array}{l}\text { Image of Politeknik Negeri } \\
\text { Jember }\end{array}$ & $\begin{array}{l}\bullet \text { Promotion media } \\
\text { Promotion activites }\end{array}$ \\
\hline Distribution & $\bullet$ Transportation route a quite easy & $\begin{array}{l}\bullet \text { Facilities } \\
\bullet \text { Human resource }\end{array}$ \\
\hline
\end{tabular}




\begin{tabular}{|l|ll|l|}
\hline Facilities and resouces & $\bullet$ Setter capacity & $\bullet$ Farm Capacity \\
& $\bullet$ Hatcher capacity & $\bullet$ Lack of Parent Stock \\
\hline Human resource & $\bullet$ Academic background & $\bullet$ Alumni interest \\
\hline
\end{tabular}

\subsection{Internal factor analysis}

The result of the internal factor is shown in Table 1. Product quality is one of the strengths of this business analysis, this is because DOC Kampung Super is the result of crosses from elder candidates who have gone through the periodic selection stage. When compared to other DOC products, the productivity of DOC Kampung Super has better performance. This can make local farmers able to accept this product for further cultivation. In addition, DOC Kampung Super continues to be tested and developed gradually until it finds a fairly high genetic uniformity, so that the quality of this final product will be more uniform. At this stage, the genetic quality of the DOC Kampung Super is quite uniform from the thousands of eggs that have been hatched. Therefore, it can be said that product quality is the main strength of the business analysis. However, the DOC Kampung Super produced by TEFA is still in small quantities, when compared to the number of requests from consumers (breeders). Several factors influence is the capacity of the cage available for rearing broodstock and the limited number of broodstock (especially males).

The price of local chicken DOC which varies greatly was a challenge in itself. Currently, there is no clear manufacturers suggested selling price (MSRP) for manufacturers regarding the price of local chicken DOC. Because in general, native chicken breeders are still on a home industry scale. With all existing facilities, TEFA can incubate approximately 1000 eggs per week. If the hatch rate reaches $80 \%$, then every month TEFA Breeding and Hatchery can produce DOC Kampung Super as many as 3200
DOC. In terms of a more efficient production capacity, for the price of DOC Kampung Super can compete with competitors. The comparison of local chicken DOC prices can be seen in Figure 2.

The price of Kampung Super DOC, which is IDR 5500 , is the lowest compared to other cruciferous chicken DOC prices. This can be an advantage but it can also be a weakness. Prices are quite low sometimes making consumers underestimate the quality of a product. Therefore, in marketing, we must rely on the image of the institution, namely the Jember State Polytechnic. As a well-known vocational campus in the Jember area, it should be able to provide its branding. And also in the promotion, it must be stated that this product is the result of research from human resources with a qualified academic background. With all the images built for these products, it was hoped that they will be able to support business opportunities from Kampung Super chicken cultivation. Not only with a good image of the institution, but promotion must also be carried out effectively and efficiently. Some of the obstacles faced by TEFA breeding and hatchery are the lack of activities and promotional media. DOC cattle produced and have been sent to farmers do not yet have a branding. Promotional activities are only carried out based on a system of relations/colleagues. Without strong branding and an effective marketing strategy, no matter how good the product quality is, the business will not develop well [6]. The development of human resources needs to boost for improving the breeding productions circle process. It is necessary to develop human resources and natural resources around the place of business to increase the effectiveness and efficiency of livestock business operations [7].

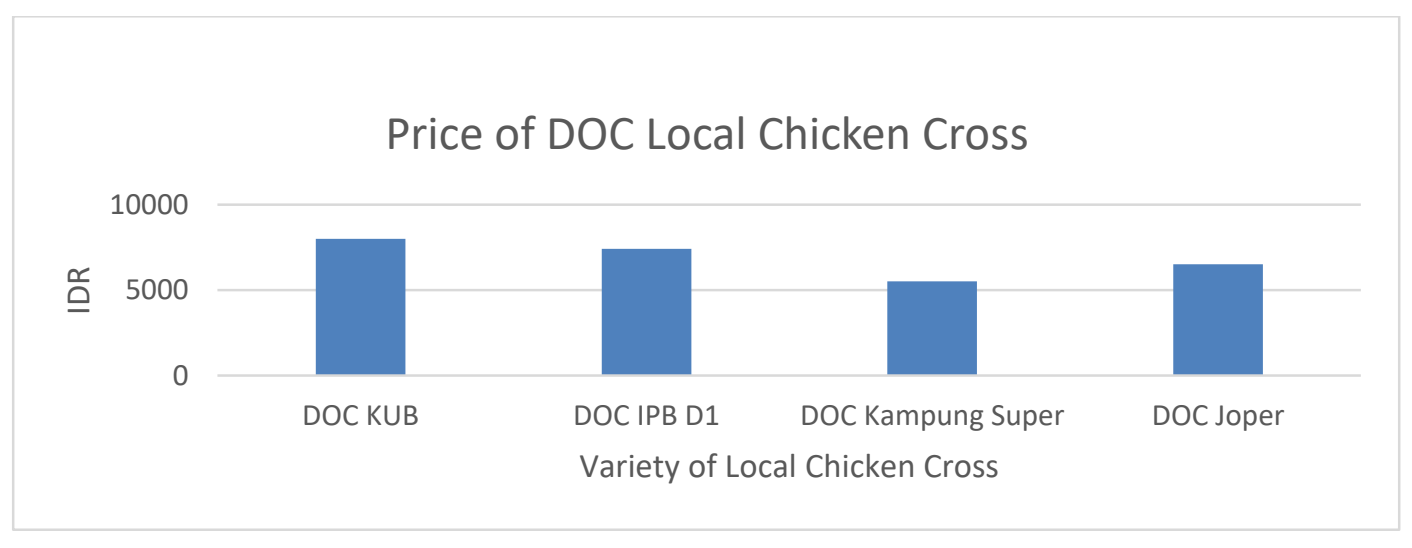

Figure 2 Comparison of local chicken DOC price 


\subsection{External factor analysis}

External factors describe opportunities and threats owned by TEFA Breeding and Hatchery. Components that are analyzed in external factors are shown in Table 2. TEFA breeding and hatchery are very likely to be developed based on several external factors that have been identified. The public's high interest in developing local chicken farming businesses and supported by the ever-increasing demand for healthy local chicken meat provides benefits for the development of TEFA breeding and hatchery businesses. The consumption of native chicken meat from 2014-2018 has increased from $0.52 \mathrm{~kg}$ to $0.73 \mathrm{~kg}$ per capita per year [8]. Another advantage identified is that the quality of similar products from competitors is not uniform so that with good broodstock, the DOC produced by TEFA breeding and hatchery can compete in the community. To support these activities, TEFA has implemented quite modern technology, namely the presence of setter and hatcher machines.

Table 2. External factors analysis

\begin{tabular}{|l|l|l|}
\hline $\begin{array}{l}\text { External factor } \\
\text { strategies }\end{array}$ & Opportunities & Threats \\
\hline Economic & $\bullet \begin{array}{l}\text { Community business } \\
\text { opportunities/interests }\end{array}$ & $\begin{array}{l}\bullet \text { Global economic conditions } \\
\bullet \text { Government economic policy }\end{array}$ \\
\hline Competitor & $\bullet \begin{array}{l}\text { The quality of competitors' } \\
\text { products are not } \\
\text { uniform/homogeneous }\end{array}$ & $\bullet \begin{array}{l}\text { Local chicken breeding business } \\
\text { in Jember and its surroundings }\end{array}$ \\
\hline Socio-cultural & $\bullet \begin{array}{l}\text { Public awareness of eating } \\
\text { healthy meat }\end{array}$ & $\bullet \begin{array}{l}\text { Livestock environmental } \\
\text { pollution issues }\end{array}$ \\
\hline Technology & $\bullet \begin{array}{l}\text { Production equipment is quite } \\
\text { modern }\end{array}$ & $\bullet \begin{array}{l}\text { Machine maintenance costs are } \\
\text { quite expensive }\end{array}$ \\
\hline
\end{tabular}

\subsection{SWOT analysis matrix to develop a business of TEFA Breeding and Hatchery}

The SWOT analysis produces a SWOT matrix consisting of four quadrants that which are possible alternative strategies that can be used to develop business, namely quadrant I: SO (Strengths and Opportunities), quadrant II: ST (Strengths and Threats), quadrant III WO (Weaknesses and Opportunities) and quadrant IV: WT (Weaknesses and Threats) [9][10]. The analysis result showed that to develop business TEFA Breeding and Hatchery should use strategies from the SWOT matrix shown in Table 3.

Table 3. SWOT matrix dan strategi yang dapat dilakukan

\begin{tabular}{|c|c|c|}
\hline & $\begin{aligned} \text { Strengths } \\
\begin{aligned} \text { 1. } & \text { Product quality } \\
\text { 2. } & \text { Price can compete } \\
\text { 3. } & \text { Image of Politeknik Negeri } \\
& \text { Jember } \\
\text { 4. } & \text { Transportation route a quite } \\
& \text { easy } \\
\text { 5. } & \text { Setter capacity } \\
\text { 6. } & \text { Hatcher capacity } \\
\text { 7. } & \text { Academic background }\end{aligned}\end{aligned}$ & $\begin{array}{ll}\text { Weaknesses } \\
\text { 1. } & \text { Production capacity } \\
\text { 2. } & \text { Underestimated quality by } \\
\text { 3. } & \text { lower price } \\
\text { 3. } & \text { Promotion media } \\
\text { 4. } & \text { Promotion activities } \\
\text { 5. } & \text { Facilities } \\
\text { 6. } & \text { Human resource } \\
\text { 7. } & \text { Farm Capacity } \\
\text { 8. } & \text { Lack of Parent Stock } \\
\text { 9. } & \text { Alumni interest } \\
\end{array}$ \\
\hline $\begin{array}{l}\text { Opportunities } \\
\text { 1. Community business } \\
\text { opportunities/interests } \\
\text { 2. } \begin{array}{l}\text { The quality of competitors' } \\
\text { products are not uniform/ } \\
\text { homogeneous }\end{array} \\
\text { 3. Public awareness of eating } \\
\text { healthy meat } \\
\text { 4. Production equipment is } \\
\text { quite modern }\end{array}$ & $\begin{array}{l}\text { Strengths-Opportunities } \\
\text { 1. } \begin{array}{l}\text { Maintaining the quality } \\
\text { product }\end{array} \\
\text { 2. Increasing genetic quality } \\
\text { 3. Increase the price following } \\
\text { the market price } \\
\text { 4. Creating promotional media } \\
\text { (stickers, logos) and holding } \\
\text { interesting promotional } \\
\text { activities (social media, } \\
\text { counselling) }\end{array}$ & $\begin{array}{l}\text { Weaknesses- Opportunities } \\
\text { 1. Creating promotional media } \\
\text { (stickers, logos) and holding } \\
\text { interesting promotional } \\
\text { activities (social media, } \\
\text { counselling) } \\
\text { 2. Increase the number of } \\
\text { cages } \\
\text { 3. Increase the number of } \\
\text { brooders }\end{array}$ \\
\hline $\begin{array}{cl}\text { Threats } & \\
\text { 1. Global economic conditions } \\
\text { 2. Government economic }\end{array}$ & $\begin{array}{l}\text { Strengths-Threats } \\
\text { 1. Fostering good relations } \\
\text { between Jember State } \\
\text { Polytechnic and farmers }\end{array}$ & $\begin{array}{l}\text { Weaknesses-Threats } \\
\text { 1. } \begin{array}{l}\text { Offering a good and } \\
\text { attractive salary for } \\
\text { prospective workers }\end{array}\end{array}$ \\
\hline
\end{tabular}




\section{3. policy}

3. Local chicken breeding business in Jember and its surroundings

4. Livestock environmental pollution issues

5. Machine maintenance costs are quite expensive
2. Counselling on environmentally friendly animal husbandry farming system
Table 3 shows several important strategies that can be used to develop a TEFA breeding and hatchery business. From the SWOT matrix above, it can be seen that the strategies that can be chosen are StrengthsOpportunities strategies. From various aspects ranging from improving product quality in terms of genetics, evaluating product prices, and optimizing marketing promotions. It is hoped that the aspects that will be improved in the SWOT matrix will have a significant impact on the development of TEFA Breeding and Hatchery.

Maintaining product quality is the main thing that needs to be done because Kampung Super DOC products in the future will be disseminated to local chicken farmers in the Jember Regency area. In fact, not only maintaining quality, TEFA Breeding and Hatchery must also continue to improve quality by making genetic improvements to Kampung Super DOC so that it is more uniform in terms of phenotype and genotype. In addition, pricing that follows the market price needs to be considered, because it is to maintain product branding and consumer stigma. This is because there are several assumptions from consumers that the price is far from the market price, which makes them question the quality of the product itself. The last strategy that needs to be implemented is the optimization of promotional media and marketing ideas. Because the product from TEFA Breeding and Hatchery, namely DOC Kampung Super is ready to compete with other crossbreed DOC chickens. DOC Kampung Super is a new product, therefore more effort is needed to introduce and socialize it to the wider breeder environment.

\section{CONCLUSION}

Based on the results of the SWOT analysis that has been carried out, the strategies that can be carried out by TEFA breeding and hatcheries to develop their business are Strengths-Opportunities strategies. From various aspects ranging from improving product quality in terms of genetics, evaluating product prices, and optimizing marketing promotions. It is hoped that the aspects that will be improved in the SWOT matrix will have a significant impact on the development of TEFA Breeding and Hatchery. In addition, the approaches taken will make Kampung Super DOC products able to be used by local chicken farmers in Jember Regency.
And from all the efforts to improve product quality, they can make Kampung Super cultivation a sustainable and profitable livestock business.

\section{AUTHORS' CONTRIBUTIONS}

Author Budi Prasetyo and Gayuh Syaikhullah conceived of the presented idea and developed a theory. Author Budi Prasetyo, Gayuh Syaikhullah and Reikha Rahmasari performed the experiments. Author Budi Prasetyo contributed to sample preparation. Authors' Gayuh Syaikhullah performed the analysis and with Budi Prasetyo wrote the manuscript with support from author Reikha Rahmasari.

\section{ACKNOWLEDGMENT}

This research was funded by Politeknik Negeri Jember through the PNBP Research Grant in 2021.

\section{REFERENCES}

[1] A. G. Nataamijaya, Pengembangan potensi ayam lokal untuk menunjang peningkatan kesejahteraan petani, J. Litbang Pertanian, 2010, pp. 131-138.

[2] A. Kholik, E. Sujana and Setiawan, Performa ayam hasil persilangan pejantan bangkok dengan betina ras petelur strain lohman, Studens e-Journals, Indonesia, 2016, pp. 1-13.

[3] I. D. G. B. Ekapriyatna, Analisis strategi pengembangan usaha peternakan ayam pedaging (broiler) ananta guna di desa sidan kecamatan gianyar kabupaten bali, J. Program Studi Pendidikan Ekonomi, Indonesia, 2016, pp. 1-13.

[4] T. I. Lestari and L. Yunita, As SWOT analysis platform in determining marketing strategy (case study on Hisana Fried Chicken Jl. Panglima Denai), Enrichment: Journal of Management, Indonesia, 2020, $\quad$ pp. 25-29. DOI: https://doi.org/10.35335/jmas.v3i1.41

[5] F. Rangkuti, Teknik Membedah Kasus Bisnis, Gramedia Pustaka Utama, 2016.

[6] S. D. Setiawati, M. Retnasari and D Fitriati, Strategi membangun branding bagi pelaku Usaha Mikro Kecil Menengah, 2019, pp. 125-136. 
[7] L. K. Wibowo, Analisa swot bisnis usaha peternakan ayam ras petelur di boyolali jawa tengah, J. of Accounting and Business Studies, Indonesia, 2019, pp. 3-11.

[8] Direktorat Jenderal Peternakan dan Kesehatan Hewan, Statistika Peternakan dan Kesehatan Hewan, Kementerian Pertanian RI, 2019.

[9] D. R. Sonia, A. Sanjaya, and M. J. Hutajulu, Business development strategies using SWOT analysis in the Cahaya Modern home industry, Jurnal Administrare: Jurnal Pemikiran Ilmiah dan Pendidikan Administrasi Perkantoran, Indonesia, 2020, pp.

117-128, DOI: https://doi.org/10.26858/ja.v7i1.14071

[10] H. Hasbullah, J. Haekal, P. R. Prayogi and D. E. A. Prasetio, Business development strategy using swot analysis method in the culinary industry, J. of Industri Engineering \& Management Research, Indonesia, 2021, pp. 53-61, DOI: 